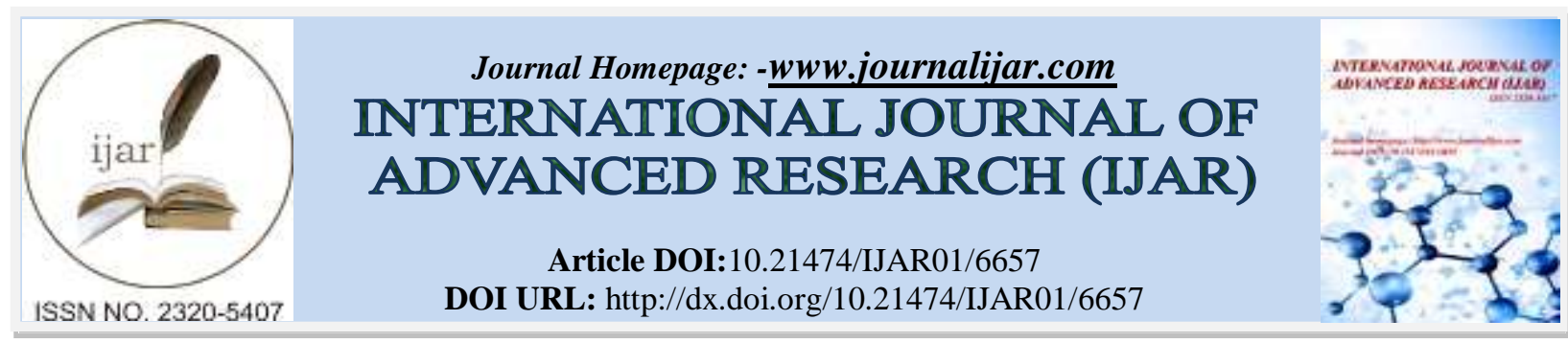

RESEARCH ARTICLE

\title{
PROJECTING THE IGNORED; SOME FUNCTIONS AND CONTEXTS OF TRADITIONAL POTTERY IN NAAKPILI COMMUNITY IN NORTHERN GHANA.
}

\section{Iddrisu Yussif ${ }^{1}$, Saaka Sulemana ${ }^{2}$ and Mohammed Abubakar Sadiq ${ }^{3}$.}

1. Assistant Lecturer, Department of Industrial Art, School of Applied Arts, Tamale Technical University P. O. Box 3 E/R, Tamale, Ghana.

2. Lecturer, Department of Industrial Art, School of Applied Arts, Tamale Technical University P. O. Box 3 E/R, Tamale, Ghana.

3. Principal Instructor, Department of Woodwork Technology, School of Engineering and Built Enveronment, Tamale Technical University P. O. Box 3 E/R, Tamale, Ghana.

\section{Manuscript Info}

Manuscript History

Received: 03 January 2018

Published: March 2018

\section{Keywords:-}

Functions, Contexts, Traditional Pottery, Naakpili
Final Accepted: 05 February 2018

\section{Abstract}

The aim of this paper was to identify and project some ignored traditional pottery functions and contexts found within the Naakpili community at Saboba district in the northern part of Ghana. As a result, emphasis was given to the identification of some functions and contexts of traditional pottery in Naakpili community. The descriptive way of qualitative research approach was used. This involved the use of case study research designs. Interview and observation were employed as a method for data collection processes. For convenience purpose, the researchers used the tabulation method of presenting findings. With this, the table was divided into three sections; inclusively were the section for the traditional name of the pot, a section for the function and a section for its context. The data were then analyzed and the indications were that, the potters make interesting forms of traditional pottery for different purposes; and the local name given to each pot perfectly defines their functions and contexts within northern Ghana. On the flipside of the coin, the function and context of every pot can also be dictated by its end user. Base on this, the researchers were able to discover some functions and contexts of the indigenous pottery which were put into some groups. On the first hand, the researchers classified the functions into five groups of purpose. These included: domestic purposes, religious purposes, rites of passage purposes and traditional herbal medicinal purposes. On other hand, seven groups of contexts were also discovered at the time of the study. These included: courtyards, bedrooms, bathrooms, graveyards, kitchens and shrines as places where these pots can be found among the people of the Naakpili.

Copy Right, IJAR, 2018,. All rights reserved.

\section{Introduction:-}

In basic Functionalist terms, if an item exists in a context it must have a reason for existing and hence it must serve some kind of function (Livesey, 2010). Prelude efforts made by researchers to define the functions and contexts of traditional pottery often involve quite a lot of concepts that seem to need widespread explanation. Since every

Corresponding Author:- IddrisuYussif.

Address:- Assistant Lecturer, Department of Industrial Art, School of Applied Arts, Tamale Technical 125 
traditional pottery produced has its moment in history - a time when it has existing context and function; and a time when the tide of social activities in their context and function flows in its favor (Crickmay, 2015). The literature on traditional pottery shows a possible method of portraying and documenting the functions and contexts sufficiently, but it is neither straight to the point nor workable enough for a successful description of their functions and contexts. This is because when indigenous pottery is not carefully used in time and properly at its defined context their functions disappear. But these are things that the researchers investigated, and for which should always seek and find direct and indirect evidence as well as truth. Commonly speaking, Context and function (with reference to traditional pottery in Ghana) are everything. They shape the meaning of all traditional pottery concurrently. Without context, traditional pottery can't function effectively. When a traditional pot is produced and delivered in one particular context, but received in another or different context it likely leads to malfunction (Bradley, 2014). What then are the word meanings of context and function? The context of a work of art refers to the cultural constraints and expectations that surrounded and influenced the artist's creation (Tmcdanel, 2013). Quite apart from this definition, Tmcdanel (2013) made it clear that, contexts of traditional pottery usually include religious beliefs of both the artist and the larger community, the political events of the time and the artist's view of those events, the work of contemporary artists, the cultural values and conflicting perspectives of the end users. On the flip side of the coin, function can be defined as the aim of a product and the way it operates. The function of a product is what you can do with it and what you achieve from it e.g. storing water is the function of a traditional water cooler (Ilse van K., Pieter Jan S. \& Prabhu K, 2005). They also did mention that, to achieve a function, a product needs to be used in a prescribed way at a given geographical area. Conclusions drawn from the above definitions indicate that, traditional pottery context and function may be separate in time, but they are often equally important to the artifact. The fact is that within milliseconds and before viewers and end users has had a chance to even think about the decorative aspect of a traditional pot; already its context and function sets an atmosphere for everything that follows. However, as far back in time as it can be told, long before we live; documentation and projection of the contexts and functions of some ignored traditional pottery in Northern part of Ghana does not exist (in books and on electronic storage devices). The research made to this effect is therefore to answer a question; what are some of the functions and contexts of existing ignored traditional pottery in Naakpili in Northern part of Ghana? In view of this, the objective for this research paper is to project as well as document the ignored contexts and functions of some identified traditional pottery in Naakpili.

\section{Concepts and Methods:- \\ Concept}

This paper aims at proper projection of some ignored traditional pottery functions and contexts at Naakpili community in northern Ghana. This was done to create worldwide awareness on the functions and contexts of pottery in Naakpili community. In addition, the study was done to ensure a proper documentation of some existing ignored pottery functions and contexts in Naakpili community.

\section{Methods}

For the purpose of this research, the qualitative research approach was adopted. The reason was that the researchers seek to understand the functions and contexts of some traditional pottery in Naapkili in northern Ghana through visiting their contexts and recording data personally. The researchers also made an analysis of what is found, an analysis fashioned by the researchers' own understanding and traditional background. The researchers also realize that the data emerge from their studies were descriptive. That is, data were reported in words (primarily the participant's audios or pictures or videos, rather than in numbers). With reference to Creswell (2003), it was clear to the researchers that this research was on participants' perceptions and experiences, and the way they make sense of their lives with traditional pottery. In other to amass data in its expected settings and make direct observations, the researchers used the case study research method. A distinguishing mark of case study research is the use of manifold data sources, an approach which also improve data reliability (Yin, 2003). Therefore, the possible data sources which the researcher used included: interviews, physical traditional pottery, audio/video recordings, direct observations, and participant-observation.

The topic and method of the study were explained to the traditional potters and end users when they were first approached. No specific kind of information was mentioned as being of particular importance for the study, nor was any information about the study concealed from them. They were assured that the study required them to spend very little extra time, although any additional time or information that they might be willing to volunteer would be more than welcome. The study was conducted in the Naapkili traditional area and the data were collected by observation and interview with no attempt to control or influence the pottery contexts and functions. The traditional pottery were 
observed, one by one, performing their regular job-related to the pottery functions and that of their contexts. Using the purposeful sampling design, ten different types of traditional pottery were observed at each individual traditional home visited in Naakpili community. The traditional potters and pottery users in Naakpili were asked to think aloud but only to the extent that such verbalization would not interfere with their pottery functions and contexts. This verbalization was recorded and transcribed base on the data collection protocol. Traditional potters and pottery users in Naakpili were observed during pottery activities base on functions and contexts. Questioning during this observation period was kept to the minimum in order to avoid any possible negative influence on human behaviour. Most traditional potters and pottery users, however, initiated conservations about their specific pottery functions and contexts. Questions during these instances attempted to keep the conservation alive and were meant to be as nondirective as possible. At the end of the observation period, when the first version of the description of traditional pottery functions and contexts were drafted, the potters and pottery users were interviewed. The interviews took the form of informal conservation which was the natural thing for the potters and pottery users to do after the researcher spend a period of time with their observation guide. The researchers asked many questions to clarify issues that arose during the observation period but could not be asked then. In the interview, questions were directed to aspects of the traditional pottery functions and contexts that were not traditionally accessible by the researchers. The recorded verbalization of the traditional potters and pottery user thought processes during the observation made, the transcribed interviews, pictures took and audio/ video recorded in Naakpili community in northern Ghana were the data collected for further discussion.

\section{Discussion:-}

Naakpili according to the researchers' studies (in June 2015) is a village (with 307 dwellings) located in the southern part of Saboba district within northern Ghana. The men in that village are noted for their hard working in the field of agriculture. Sincerely speaking, in terms of craftsmanship, the women in Naakpili are more recognize than any other person in or around that place. Not being versatile artists, they are craftswomen with a very high level of creativity which make their pots stand tall when they are in the midst of others from assorted pottery centers in northern Ghana. This segment contains some studies made on traditional pottery functions and contexts in Naakpili in the northern part of Ghana. Clearly speaking, before the researchers could determine the ignored functions and contexts of our traditional pottery, their focus was entirely based on their local names. This is simply because; the local name of a traditional pot perfectly defines its functions and context within the northern part of Ghana. The table below is a set up of the various ignored functions and contexts of traditional pottery identified by the researchers in Naakpili. Generally, the table is divided into three columns; that is, the local name of the pot, its function and lastly its context.

Table 1:- Studies on some traditional pottery functions and contexts in Naakpili

\begin{tabular}{|l|l|l|}
\hline Local Name & Function & Context \\
\hline Plate 1: Lijaabul (the fetish pot) & $\begin{array}{l}\text { For the purpose of } \\
\text { containing the spirit of } \\
\text { their ancestors in the form } \\
\text { of "pito". }\end{array}$ & $\begin{array}{l}\text { It is priest or at the shrine. } \\
\text { of a pried }\end{array}$ \\
\hline
\end{tabular}




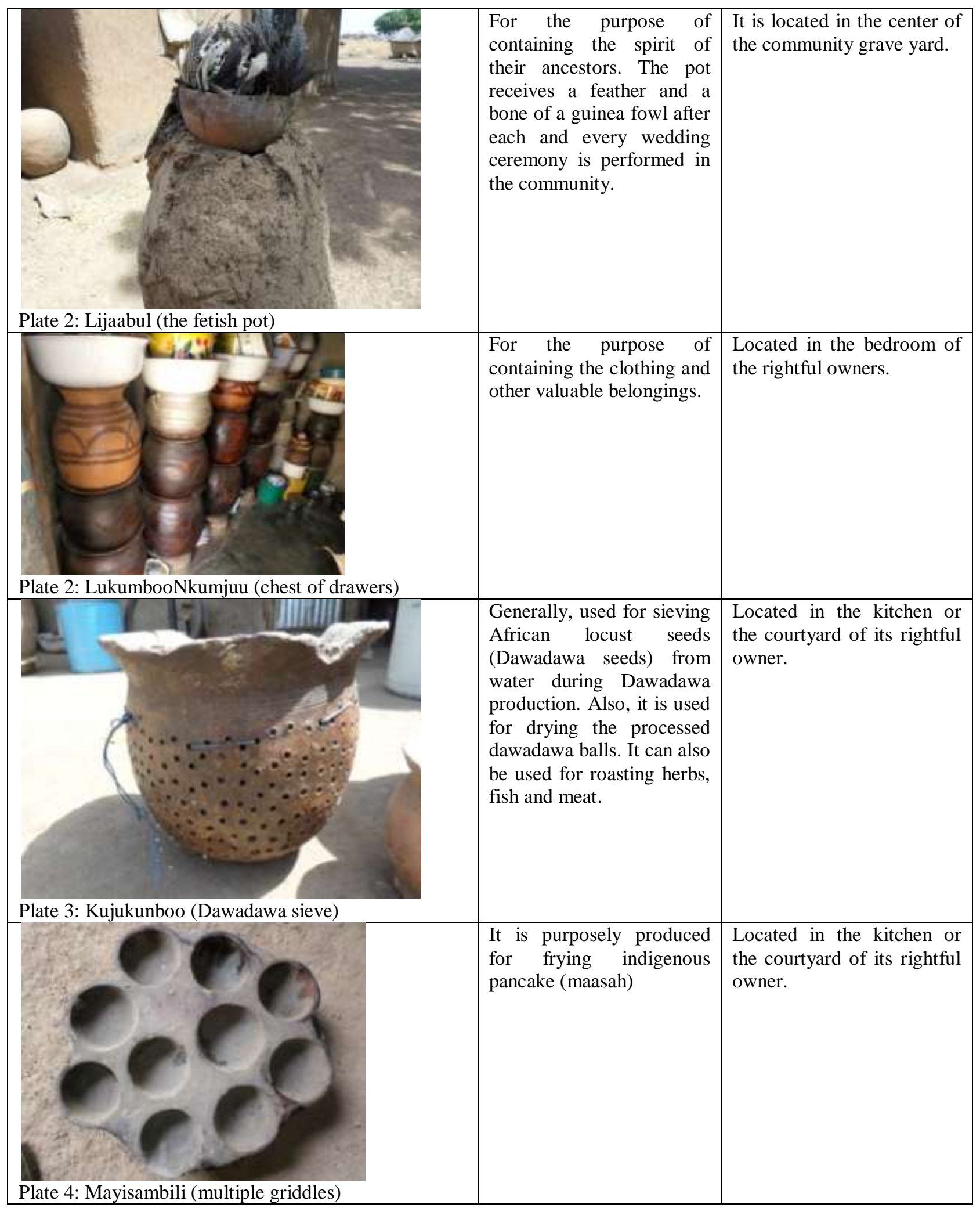




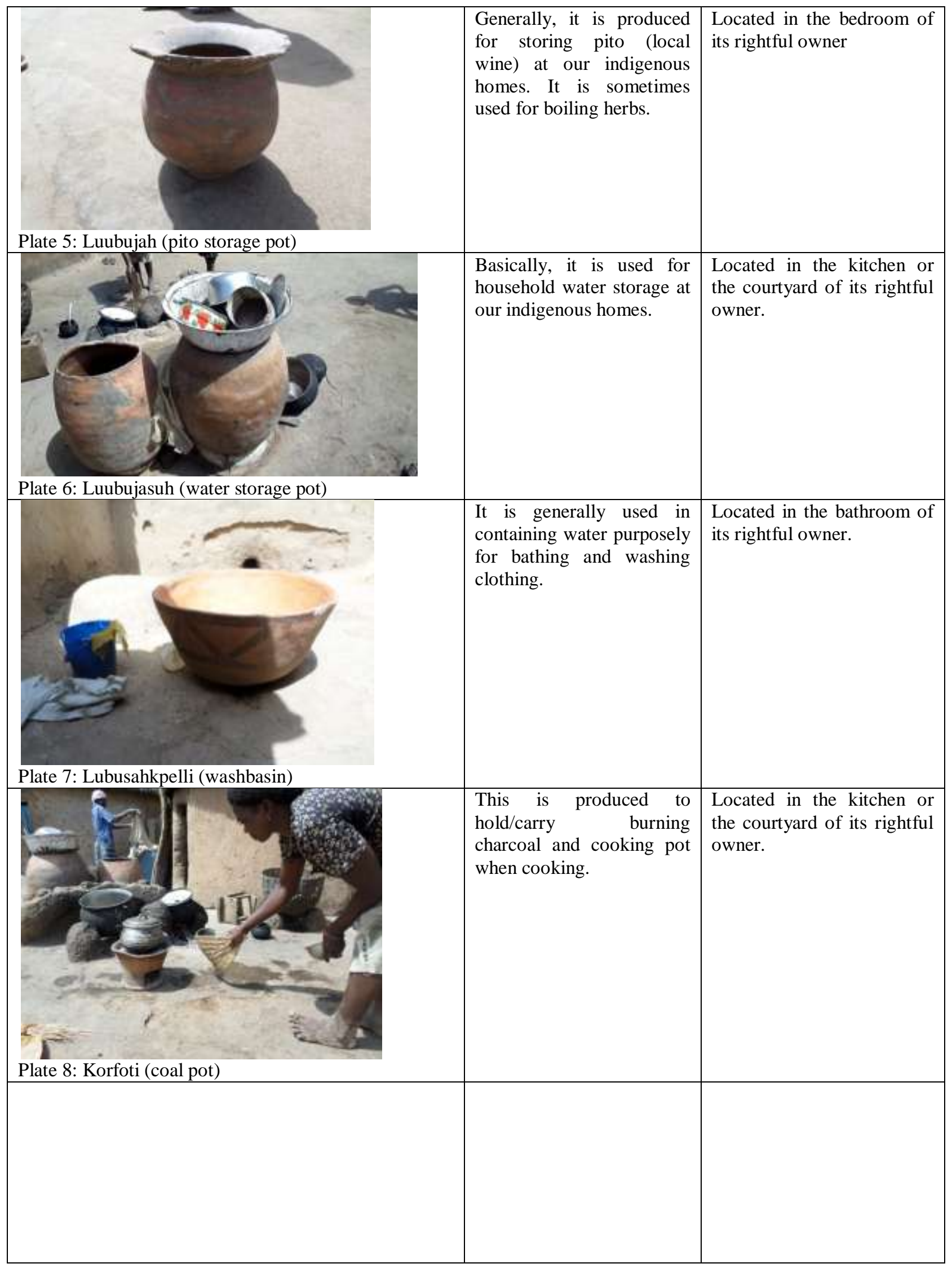




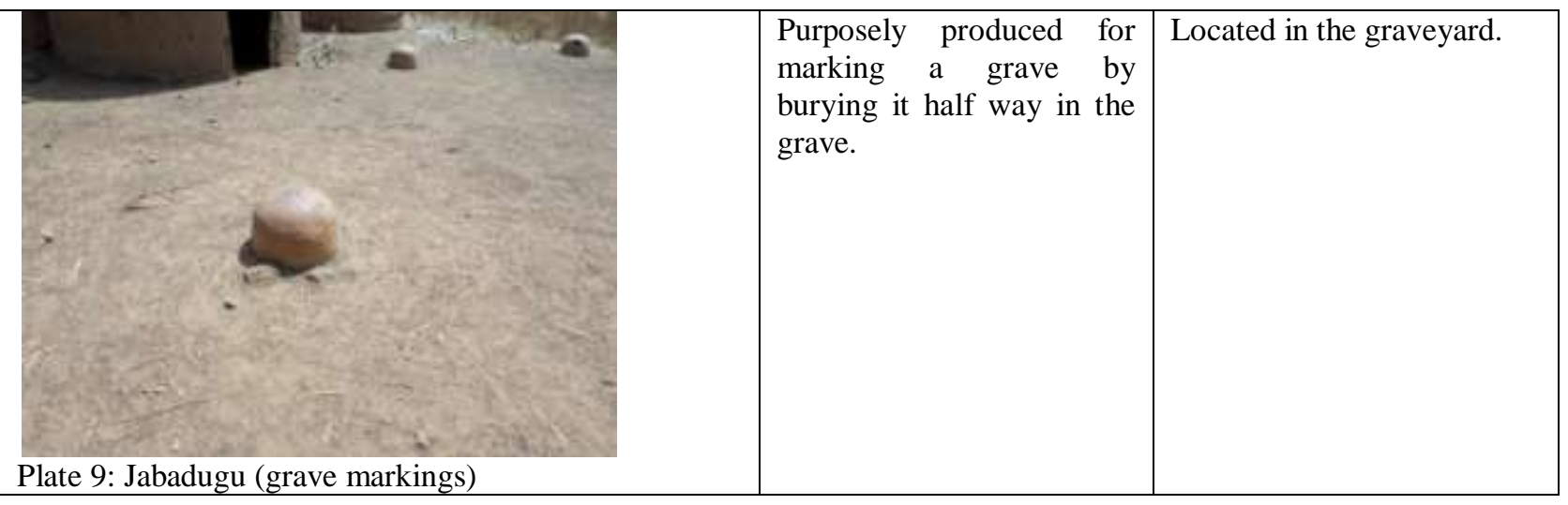

\section{Conclusion:-}

In conclusion, studies made by the researchers clearly show that the ignored traditional pottery found in Naakpili is generally produced from the idea of domestic functions, religious functions, and rites of passage functions. On the flip side of the coin, contexts of ignored traditional pottery found at Naakpili included the courtyard, bedroom, bathroom, graveyard and the kitchen of their rightful owners.

\section{Recommendations:-}

The study made by the researchers' shows that some associated ignored functions and contexts of traditional pottery in Naakpili community is dying off (due to the higher demand of modern domestic metallic and plastic utilitarian goods). It is therefore recommended that research should be done on these potteries in other to project and document their functions and contexts and how they can be brought back to life.

Even though, studies have been made on the projection of the ignored functions and contexts of traditional pottery in Naakpili community in northern Ghana, it is recommended that studies and projections should also be made on the ignored forming and firing techniques of traditional pottery in Naakpili community.

It is also recommended that, research work should be done on the ignored concepts associated with traditional decorative techniques on pottery in Naakpili community.

Finally the researchers recommend that, studies should be done on the influence of African aesthetics on traditional pottery in northern Ghana.

\section{References:-}

1. Bell, J. (2010). DoING Your RESEARCH PROJECT: A GUIDE FOR FIRST-TIME RESEARCHERS IN EDUCATION, HEALTH AND SOCIAL SCIENCE. LONDON: OPEN UNIVERSITY PRESS.

2. Bradley, S. (2014, June 26). The Importance Of Context. Retrieved September 7, 2016, from Vanseo Design: http://vanseodesign.com/web-design/importance-context/

3. Crickmay, C. (2015, May 13). ART AND SOCIAL CONTEXT contextual art practice in education. Retrieved September 6, 2016, from David Harding: http://www.davidharding.net/\%3Fpage_id\%3D22

4. Decorative Applied Art. (1970-1979). Retrieved June 15, 2016, from The Great Soviet Encyclopedia, 3rd Edition: http://encyclopedia2.thefreedictionary.com/Decorative+Applied+Art

5. Function . (2015, September 21). Retrieved September 24, 2016, from Merriam-Webster: http://www.merriamwebster.com/dictionary/function

6. Livesey, C. (2010). Functionalist Theories. Retrieved September 18, 2016, from Sociology Central Crime and Deviance: www.sociology.org.uk

7. Rouse, M. (2005 , September 3). Functions. Retrieved September 21, 2016, from Computing fundamentals glossary: http://farside.ph.utexas.edu/teaching/329/lectures/node17.html

8. Shepard, A. O. (1956). Ceramics for the archaeologist. Wasshington D.C: Carnegie Institution of Washington.

9. Tmcdanel. (2013, February 25). What is a definition of context in art terms? Retrieved September 7, 2016, from Answers: http://www.answers.com/Q/What_is_a_definition_of_context_in_art_terms 